\title{
Unfinished harvest: Plants and patents
}

\author{
Peter Dehlinger
}

\author{
Intellectual Property Rights in \\ Agricultural Biotechnology \\ Edited by F.H. Erbisch and K.M. Maredia \\ 1998 CAB International, \\ 224 pages, $\$ 80$ hardcover
}

The last two decades have seen a dramatic shift in the type and scope of intellectual property rights (IPR) available to plant-science inventors. Where plant scientists once relied on plant variety protection (PVP) to cover new varieties of sexually reproducing plants, today's plant genetic engineers look to utility patents to obtain relatively broad patent claims covering fundamental plant discoveries and modifications.

With this shift in available patent protection have come new perspectives on how IP portfolios in plant sciences should be managed. To a university licensing office or a corporation engaged in plant research, patent protection on new plant discoveries may justify an aggressive patent strategy that involves active patent licensing and enforcement, and a hefty budget for foreign patent costs.

This shift also raises new social-policy questions related to food as a commodity for IPR. To what extent will patents on improved plants increase the economic pressures on small, independent farmers? Will patent costs show up in the form of higher costs at the supermarket? Will economically distressed countries be exempt from patent tariffs on their foods?

Intellectual Property Rights in Agricultural Biotechnology, the 20th volume in a series on "Biotechnology in Agriculture," provides an introductory guide for inventors, IP lawyers, and other participants in universities, government, and industry seeking to understand the changing landscape of IPR in agricultural biotechnology. While prior volumes in the series have dealt with various scientific aspects of plants, this one focuses entirely on intellectual property issues. The book's contributors include IP lawyers, university licensing officials (the two editors among them), and corporate and policy-center representatives.

The first part of the book deals with the general issues and principles of plant IPR, beginning with a survey of the basic concepts underlying patents, trademarks, copyrights, trade secrets, and plant variety protection (PVP), with an emphasis on US patent law. The survey is adequate, but needs more exam-

Peter Dehlinger is a biotechnology patent attorney practicing in Palo Alto, CA (peter@dehlinger.com). ples from the world of plant inventions.

It is followed by a more thought-provoking discussion on acquiring protection for improved germplasm and inbred lines that touches on the interrelationships between IP and biodiversity, and provides the reader with a comparison of the types of protection available through PVP and utility patents. Author John H. Barton notes two plant patent infringement cases as evidence of a rising tide of plant-patent litigation. Barton's chapter was presumably too early to press to discuss the implications of the Pioneer Hi-Bred v. Farm Advantage case now before the Court of

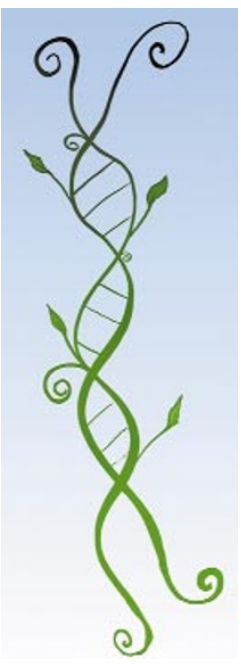
Appeals for the Federal

Circuit (see Nature Biotechnology 17, 717-718; 1999). This case raises the fundamental issue of whether the US Congress intended major food crops to be patentable. Although the court is expected to uphold the legality of plant patents, it could conclude that the matter needs to be formally addressed by Congress.

The structure of technology license agreements is outlined in the third chapter, as well as the types of licensing provisions that must be considered. The chapter is, unfortunately, short on discussion of licensing problems peculiar to agricultural technology-for example, the problems of licensing a product that is both renewable and changeable. The next chapter, written by the editors, outlines efforts to create policy, networking, and management structures for agricultural biotech at both the national and institutional (in this case, Michigan State University) levels. Those involved in the management of agricultural technology will find this chapter of interest.

The second part of the book contains expositions of IP laws in 11 selected countries/regions. Here, one is struck by how unsettled IP law in agriculture is around the world. This point is illustrated in the chapter discussing plant IPR in the European Union, which should be one of the more stable IP forums. The chapter compares patent protection available in the EU under the International Union for the Protection of New Varieties of Plant (UPOV), as amended in 1991, and through conventional utility patents. Most patent practitioners believe Europe is moving in the direction of offering broad patent protection on genetically engineered plants and plant cells, but occasional political hiccups seem to keep this issue in flux (see Nature Biotechnology 17, 198; 1999).

Discussions on the plant IP situation in developing countries were equally interesting, but for an entirely different reason. One can see a subtext in these chapters that IP rights to agricultural products need to be considered in the framework of growing and supplying adequate amounts of food without burdening the society unduly with IP costs. It is fair to say that developing countries are caught between the demands for attracting foreign investment and technology, with its dependence on an effective IP system, and the lack of any real will to impose additional costs on the society. Although most countries are now signatories to the General Agreement on Tariffs and Trade (GATT), and therefore expected to implement the clauses under the Trade-Related Aspects of Intellectual Property Rights (TRIPs), a member country is allowed under Article 27 of TRIPs to exclude from patent protection, "plants and animals, other than microorganisms, and essentially biological processes for the production of plants and animals, other than non-biological process and microbiological processes." This exemption would appear to give developing countries the ability to move toward internationally recognized standards of IPR, without being forced to adopt a position on plant patents that is as industry-driven as that, say, in the US.

Although the book is adequate in its treatment of the basic issues, it is not ambitious. Why not include, for example, a chapter that surveys the market sizes and crop production levels of major agricultural countries, to help companies decide where limited funds should be allocated to achieve the best global IPR? Some discussion of the International Rice Research Institute in the Philippines, as a model for improving crop plants largely outside of IP systems, would have been instructive. Finally, looking ahead, it would be helpful to have a companion text covering the regulatory hurdles faced by new plant technologies.

In summary, this book provides a readable introduction and overview of the changing, yet to be settled, intellectual property landscape in plant biotechnology. One hopes that the book will be on the bookshelves of policy makers as they struggle with the challenge of fashioning effective worldwide IPR for plant inventions. 